\title{
PODCAST
}

\section{Forum: First human trial of engineered T cells}

Senior Editor Markus Elsner talks to Alex Marson of UCSF about the significance of a Science paper describing the phase 1 clinical trial of CRISPR-engineered T cells. The work was carried out by a team led by Carl June and Edward Stadtmauer from UPenn. Read the paper at https://doi.org/10.1126/science.aba7365. https://aca.st/29001d

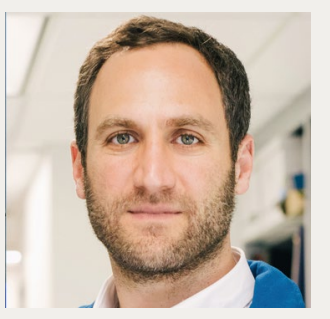

Published online: 19 May 2020

https://doi.org/10.1038/s41587-020-0544-X

\section{PODCAST}

\section{Forum: Worms and gut microbes team up to kill corn pest}

David Shapiro Ilan talks to Senior Editor Susan Jones about a paper in the May issue in which Ricardo Machado and colleagues describe how they evolved bacterial symbionts of nematodes to help these worms kill a devastating crop pest: the western corn rootworm. The paper can be read at https://doi.org/10.1038/s41587-020-0419-1. https://aca.st/95bba9

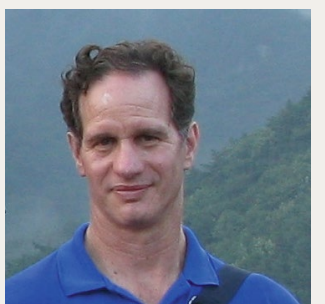

Published online: 19 May 2020

https://doi.org/10.1038/s41587-020-0543-y

\section{PODCAST}

\section{First rounders: Alexis Borisy}

Alexis Borisy is CEO and chairman of EQRx, and a long-time biotech builder with Third Rock Ventures. His conversation with Nature Biotechnology covers growing up as a 'faculty brat' in Wisconsin, dropping out of his PhD program at Harvard and why, even to an investor, biotech cannot be all about the money.

https://aca.st/8c2649

Published online: 21 May 2020

https://doi.org/10.1038/s41587-020-0542-z 